\title{
Culturally modified trees and forest structure at a Kawésqar ancient settlement at Río Batchelor, western Patagonia
}

\author{
Lars Östlund ${ }^{1} \cdot$ Gabriel Zegers ${ }^{2} \cdot$ Benjamin Cáceres Murrie ${ }^{2} \cdot$ Macarena Fernández $^{3} \cdot$ Robert Carracedo-Recasens $^{4}$. \\ Torbjörn Josefsson $^{1}$ • Alfredo Prieto ${ }^{5}$. Samuel Roturier ${ }^{6}$ (D)
}

Accepted: 18 October 2020 / Published online: 17 November 2020

(C) The Author(s) 2020

\begin{abstract}
Indigenous land use occurring on temporal scales over centuries or millennia shapes forests in specific ways and influences the dynamics of forest ecosystems. It is challenging to study such land use, but analysis of "culturally modified trees" (CMTs) can give precise spatial and temporal information on past land use by indigenous people. The aim of this study was to increase our knowledge of indigenous use of land and resources in Nothofagus forests by identifying CMTs and analyzing the forest structure dynamics in an ancient Kawésqar settlement site in western Patagonia. Our results show that there are CMTs at Río Batchelor and that the forest structure varies significantly within the site, indicating that Kawésqar people altered the forest by extracting various resources. We conclude that CMT studies have great potential in Nothofagus forests in southernmost America, but also face specific challenges due to environmental conditions and lack of corroborating historical information.
\end{abstract}

Keywords Culturally modified trees $\cdot$ Bark peeling $\cdot$ Forest history $\cdot$ Indigenous land use $\cdot$ Archaeology Patagonia $\cdot$ Nothofagus

\section{Introduction}

Indigenous peoples' long-term land use and the legacy of human imprints on forest ecosystems have gained increasing attention during recent decades (e.g. Thompson et al. 2002; Bayliss-Smith et al. 2003; Heckenberger et al. 2003; Josefsson et al. 2010; Buergi et al. 2017). Low intensity but spatially broad and occurring on a scale over centuries or even millennia, human activities shape forests in specific ways and also influence the dynamics of forest ecosystems. Yet to date not much attention has been given to the southernmost parts of the South American rainforests in this respect, including

Samuel Roturier

samuel.roturier@universite-paris-saclay.fr

1 Department of Forest Ecology and Management, Swedish University of Agricultural Sciences, 90183 Umeå, Sweden

2 Asociación de Investigadores de Museo de Historia Natural Río Seco, Punta Arenas, Chile

3 Centro Regional Fundación CEQUA, Punta Arenas, Chile

4 Departament de Prehistòria, Universitat Autònoma de Barcelona, 08193 Barcelona, Spain

5 CIGA, Universidad de Magallanes, Punta Arenas, Chile

6 Ecologie Systématique et Evolution, Université Paris-Saclay, CNRS, AgroParisTech, 91405 Orsay, France western Patagonia - a region rich in research potential. Culturally modified trees (CMTs) are cultural imprints that can provide precise information, spatially and temporally, on historic and pre-historic land-use (see Mobley and Eldridge 1992; Prince 2001; Östlund et al. 2002, 2009; Turner et al. 2009; Rautio et al. 2014): studies such as these complement archaeological and anthropological research where historical sources are scarce.

The Patagonian archipelago covers about one million $\mathrm{km}^{2}$ at the southern cone of the American continent. This vast area includes contrasting environments, such as seascapes, rainforests, tree-less pampas, valleys and mountains of the alpine Andes from Puerto Montt $\left(41^{\circ} \mathrm{S}\right)$ to Cape Horn $\left(54^{\circ} \mathrm{S}\right)$. In this region there is evidence of human occupation dating back to the late Pleistocene $c .14,000$ cal years BP (Dillehay et al. 2008, 2015; Prieto and Labarca 2011). The distribution of archaeological sites in the region shows evidence of mobile hunter-gatherer groups with distinctive, shared characteristics in material culture spread over large areas and a wide variety of resource utilization, both marine and terrestrial (Orquera and Piana 1987). For more than 6,000 years, the Kawésqar and Yagán indigenous peoples have used the fragmented seascape as nomads, using canoes to navigate through the fjords and channels from the Gulf of Penas to the end of Tierra del Fuego Island including Cape Horn until the late $19^{\text {th }}$ and early twentieth centuries 
(Emperaire 1955; Gusinde 1986, 1991; Chapman 2012). This livelihood disappeared during the twentieth century as a result of 400 years of colonization, forced relocation and assimilation of the indigenous communities (Emperaire 1955). Hunting and gathering benthic organisms was complemented to some extent with land game and vegetables (Orquera and Piana 2000; Piana and Orquera 2009; San Román et al. 2002). Stranded whales were also an important but intermittent food source. This livelihood and resource use created well-known shell middens, which are the characteristic remains of the long-time process of collecting and eating of shellfish and other animals that accumulated around the settlement sites, creating a typical concave shape (e.g. Orquera et al. 2011).

Notwithstanding the high dependence on marine resources, these peoples were also strongly connected to forest resources. From previous archaeological and anthropological research, it is clear that the Nothofagus coastal rainforests provided many important resources that were crucial for survival in the Patagonian archipelago. Settlement sites were most often located in sheltered bays protected from wind, in secluded settings and with ready availability of fresh water. These sites were used repeatedly over time. Trees were used for a variety of purposes including firewood, the construction of huts, the manufacture of tools and equipment, food and medicine (Orquera and Piana 1987; Bjerck 2009; Zárraga 2016). In particular, the bark of Nothofagus betuloides was peeled to build canoes, which were essential to the sea nomads' livelihood, and produce various items such as ceremonial masks or buckets (Emperaire 1955; Gusinde 1986, 1991; Legoupil and Lira 2017), as well as a possible food source (Zárraga 2016, pers. comm. Gonzáles Gonzáles and Gonzáles Calderón).

CMTs, such as bark-peeled $N$. betuloides, can document direct or indirect use of forest and trees by indigenous people. By using dendrochronological methods on them, CMTs can not only provide temporal precision (Andersson 2005; Rautio et al. 2014), but also precise information about human movement within forests and also the use of specific forest resources, notably the utilization of tree bark for construction and household items (Steward 1984), or the use of inner-bark as an important food source (Prince 2001; Rautio et al. 2014). Accordingly, linking historical and archaeological information with analysis of CMTs and historic forest structure is one possible road forward to getting a broader picture of the habitation and resource use of indigenous peoples in the past (Josefsson et al. 2010; Heffner and Heffner 2012; Rautio et al. 2014; Larson et al. 2019).

The aim of this study was to increase our knowledge of indigenous peoples' use of land and resources in Nothofagus forests by identifying CMTs and analyzing forest structure dynamics on an ancient Kawésqar settlement site in western Patagonia in Chile. We focused on the use of land and resources over the last 400 years at and near the settlement site using analyses of bark-peeled trees and forest structure. This timeframe was chosen because it is covered by both biological (tree rings) and archaeological and historical records. The objectives of the study were to: (1) identify and describe attributes and the spatial and temporal distribution of bark-peeled trees; (2) compare characteristics of bark-peelings to Kawésqar and Yágan bark objects kept in museum collections; and (3) analyze the relationship between barkpeeled trees, present forest structure and the settlement site. The analyses made in this study forms the basis for a more general discussion of the potential and challenges for CMT studies at indigenous settlement sites in southern rainforest ecosystems.

\section{Material and methods}

\section{The Río Batchelor site}

The study site $\left(53^{\circ} 33^{\prime} \mathrm{S}, 72^{\circ} 18^{\prime} \mathrm{W}\right)$ is located on the southernmost part of the mainland of western Patagonia in Chile (Fig. 1), in the Magellanic rainforest vegetation zone (Veblen 2007). We selected the site based on the following criteria: (1) a late successional coastal Nothofagus forest, (2) in an area with known historical land use by the Kawésqar people, with (3) no known history of commercial forest utilization nor (4) modern infrastructure or habitation. The main archaeological site (named Batchelor I, see San Román et al. 2002; Prieto et al. 2008) is located at $3 \mathrm{~m}$ asl on a sheltered north-western bank near the river, and in estuarine waters about $150 \mathrm{~m}$ from the sea. The site has a flat topography and includes some $30 \mathrm{ha}$ of forest on both sides of the estuary where the Batchelor river enters the sea (Fig. 2a).

The forest is dominated by evergreen Nothofagus betuloides with a minor component of Drimys winteri and Maytenus magellanica. Most parts of the forest are in latesuccessional stages, and the closed-canopy forest has a multi-aged tree structure with trees of different ages intermixed (Fig. 2b). The ground flora is typical of pure evergreen $N$. betuloides forest in the area (Cruz and Caldentey 2007), and includes woody vines Luzuriaga marginata and Lebetanthus myrsinites, shrubs Berberis ilicifolia, Philesia magellanica, Desfontainia spinosa, Fuchsia magellanica and Empetrum rubrum, and ferns Blechnum magellanicum and Hymenophyllum tortuosum that thrive on the forest floor and lower part of the largest tree trunks. A cold-temperate climate with great humidity (Pisano 1981) and moderate to cool summers and snowy winters characterize the region. Temperature is greatly moderated by proximity to the ocean, with average lows in July and highs in January.

The indigenous Kawésqar people have inhabited the local region where the Río Batchelor site is situated for centuries. 


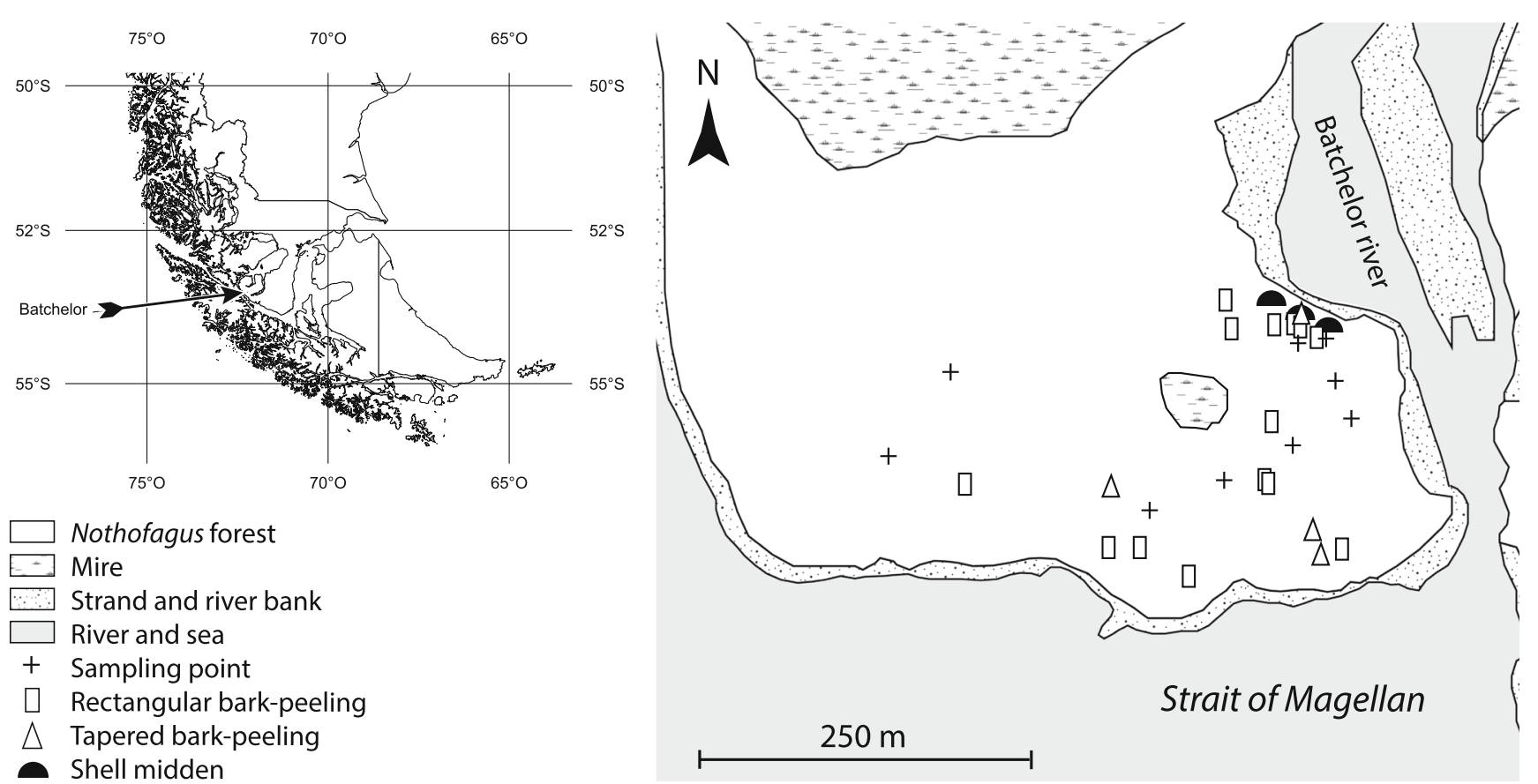

Fig. 1 Location (upper left) and map of the study site (right) with major vegetation types, the ancient settlement at Batchelor I (indicated by shell middens), sample points and positions of registered culturally modified trees

Early written accounts of this region include that of Pedro Sarmiento de Gamboa who disembarked at Carlos III Island and erected a cross on it in the sixteenth century (Sarmiento de Gamboa 1950). However, the most informative source from the Batchelor river area is the account of Beauchesne's French expedition to the Pacific in 1698-1701 (Duplessis 2003). Later records include a description by Phillip Parker King and Robert FitzRoy who in 1829 mentioned 14 people travelling in a canoe on the Batchelor river, and Carl Skottsberg from the Swedish Magellan scientific expedition that in 1907 noted some abandoned awnings near the river (Prieto et al. 2008), this being the last historical record of indigenous use of the settlement site. More recently, José Emperaire encountered a group of indigenous canoers, probably Kawésqar, in Bahía de Gallant, located roughly $30 \mathrm{~km}$ from Río Batchelor (Passini 1951). The site has no history of commercial forest management, and except for some recent small-scale fishing and archaeological excavations in the early twenty-first century there are no records of human activities during the last 70 years. The site is presently uninhabited and located more than $75 \mathrm{~km}$ from the nearest road or house.

\section{Archaeological review and recent history at Río Batchelor}

The site was excavated in 2000 and 2005 by the Centro de Estudios del Hombre Austral - Instituto de la Patagonia (San Román et al. 2002). These excavations uncovered direct evidence of sporadic indigenous camps and repeated occupations, materialized in the form of shell middens among the vegetation or near the shores. According to these results, the most common remains found in the middens were shells of common shellfish, but the bones of mammals and birds were also present. Tools and other cultural objects were also in evidence. The site contained not only indigenous material, but also European contact material such as retouched bottle glass, which allowed for indirect dating complementary to ${ }^{14} \mathrm{C}$ dating (Beta-163547 220 + $60 \mathrm{BP}$ ). The conclusion, based on the materials and dating, is that the site was probably occupied between the seventeenth and nineteenth century (San Román et al. 2002; Prieto et al. 2008). Indications of carving activities, traces of cuts and evidences of cooking on remains were also found, showing that people were cooking and living in the settlement for significant periods of times. Based on this previous research we did a reconnaissance archaeological survey to identify and locate with certainty the archaeological settlement at Batchelor I, and determine possible traces of other settlements in the peninsula. In connection with this survey we performed an inventory of cut stumps and other traces of logging in the peninsula to confirm the absence of commercial forest management.

\section{Ethnographic records of the use of bark in south- western Patagonia}

A literature review was conducted of the main ethnographical and historical records of the material and technical uses of 

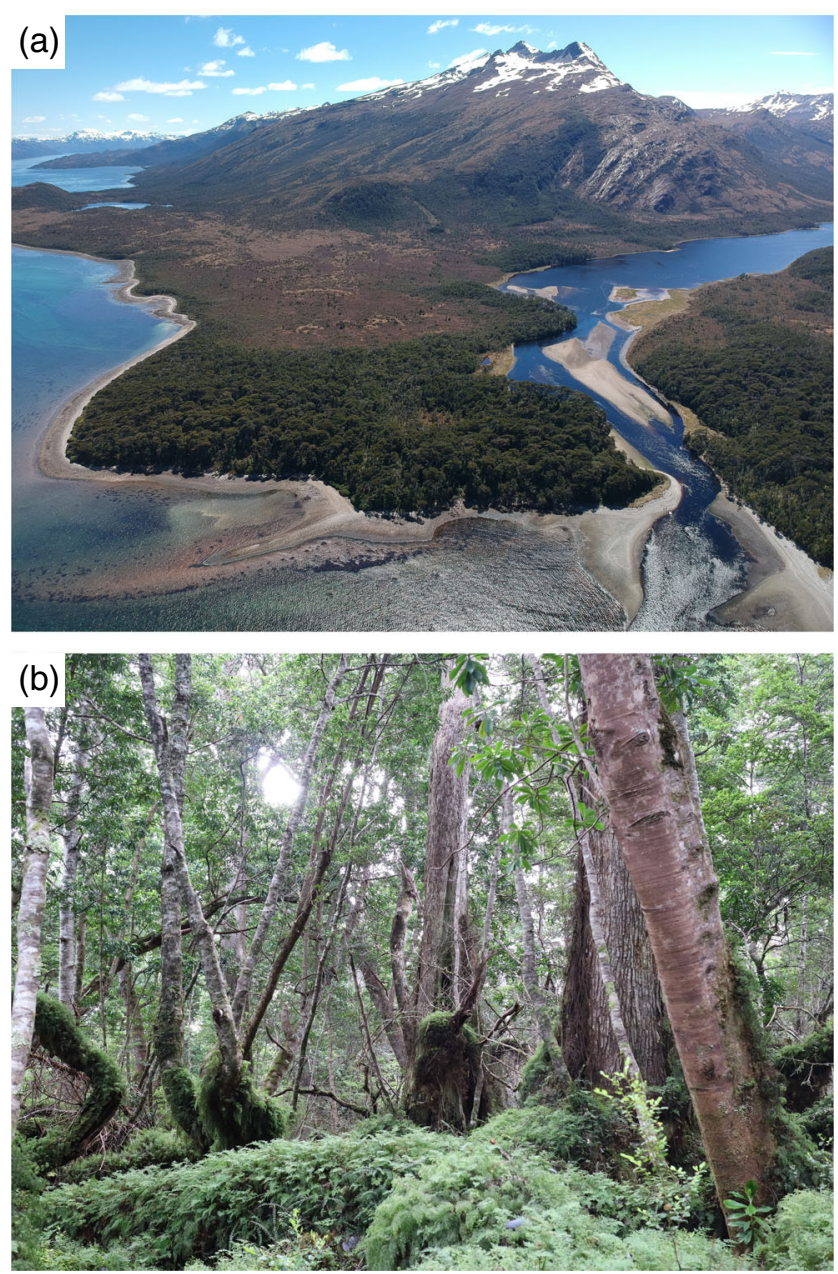

Fig. 2 a Aerial photo showing the Río Batchelor site from the south-west; the Batchelor river outlet to the right and the Strait of Magellan to the left (Photo: Federico Guerrero); $\mathbf{b}$ typical forest structure in the interior parts of the study site with older and younger Nothofagus betuloides trees mixed with Drimys winteri trees. Understory vegetation is dominated by ferns and a thick moss layer (Photo: Lars Östlund)

bark (e.g. tools for bark extraction and work, cut-marks in trees) (Emperaire 1955; Martínez-Corvetto 1968; Chapman 2012; Zárraga 2016). To enable interpretations of the possible use of tree bark we performed a superficial survey of objects made of bark that are presently kept at different museum collections around the world (Salesianos Museum, Punta Arenas, Chile; the Musée du Quai Branly - Jacques Chirac, Paris, France; the British Museum, London, UK; the Museo Misionero Etnológico, Vatican; Weltmuseum Wien, Vienna, Austria; and the Museum of World Culture, Gothenburg and the Ethnographical Museum, Stockholm, Sweden). All of the examined bark objects belong to the Kawésqar and Yagán people (Vila-Mitjà and Estévez Escalera 2017). We found 12 bark objects, including buckets, beakers, ritual masks and a canoe scoop (see supplementary material) that could be attributed to the Kawésqar. These objects (mainly collected and then preserved to the present time entirely by chance), admittedly few in number, still give a clear testimony of the rich
Nothofagus bark use by indigenous people in Patagonia. Canoes and small canoe models were excluded. The dimensions of these objects were compared to the dimensions of the bark-peelings inventoried at the study site in order to assess a possible size relationship between bark-peelings and use of the bark.

\section{Field survey of CMTs}

CMTs were surveyed within a 15 ha large area covering the western part of the study site (Fig. 1). The survey was designed to locate traces of past human land use including bark-peeled trees (Andersson et al. 2008). CMTs were inventoried through a systematic transect sampling. With the aid of a GPS we laid out $20 \mathrm{~m}$ wide transects parallel to the seashore. Each transect was inventoried by three people, and all trees within the transects were examined for CMTs and other peelings. The area in the center of the small peninsula contains a mire and was excluded from the inventory. In total, 3.4 ha were surveyed for CMTs. All recorded peels were examined and classified according to experience of CMTs from other studies (cf. Östlund et al. 2009, and the CMT Handbook 2001). To finally distinguish between natural scars (e.g. scars made by falling trees or left by fire) and human-made peelings we performed a two-step analysis. In the field, we checked carefully for fallen trunks or branches which could explain scars of natural origin. When all data was collected we also made a comparative analysis of the size and shape of the peels, presence of toolmarks, positions on the trunk to further verify the bark-peelings. Each classified tree was then positioned with a GPS and photographed. The following parameters were recorded for each bark-peeling: tree species, diameter at breast height (DBH), length and width of the peel, distance from ground to the lowermost part of the peel, presence of axe-marks and/or knife-marks on the peel; in addition, the presence of any charcoal from forest fire on the peel was noted and a careful measurement of the depth of the encroachment was also made.

\section{Field survey of forest characteristics}

To examine the current forest structure and composition we established a total of nine sampling points, with the first point on the overgrown settlement site (Josefsson et al. 2010). The remaining eight sampling points were placed successively in a random way at various distances and angles up to $c .350 \mathrm{~m}$ from the first point (Fig. 1). At each sampling point we recorded the heights of the two largest trees (within a $20 \mathrm{~m}$ radius), basal area (total and for each tree species using a relascope), the DBH for trees $(\geq 5 \mathrm{~cm})$ counted with the relascope. We also recorded the characteristics of standing (snags and stumps $\geq 2 \mathrm{~m}$ high) and lying ( $\geq 1 \mathrm{~m}$ long, $\geq$ $10 \mathrm{~cm}$ in diameter in the thick end) dead trees, within a 0.4 ha quadrat positioned south-west of the centre of the sampling point. To determine the stand age, six living trees were 
randomly selected and cored at each sampling point, using increment borers ( 4.5 and $12 \mathrm{~mm}$ in diameter). All samples were taken at breast height ( $1.3 \mathrm{~m}$ above the ground) to avoid rot and irregularities in ring sequences. To determine the time needed for a tree to reach breast height, and to allow us to compensate for this in our calculations, disk samples from $1.3 \mathrm{~m}$ high trees $(n=30)$ were taken from the base of the tree, as near the germination as possible.

\section{Laboratory procedures and data analysis}

Tree age was determined in the laboratory by annual ring counts using standard methods. The sampled tree cores were mounted and prepared with sandpaper (100 and 400 grades) and chalk to make the annual rings clearly visible. All samples were then measured using a microscope at $6.4 \times$ to $40 \times$ magnification and a tree ring measuring station with a resolution of 1/100 mm (LINTAB 5, RINNTECH Technologies). We dealt with age-approximation of trees for which the increment cores failed to reach the pith by estimating the length of the missing part of the radius by matching the curvature of the inner rings to concentric circles drawn on a transparent plastic sheet (cf. Josefsson et al. 2010). The total tree age was determined by adding the average age of $1.3 \mathrm{~m}$ tall trees (nine years) to the estimated ages of trees cored at breast height.

Volume $(V)$ of standing dead trees was assessed using the formula (Promis 2006):

$V=0,000136 \times d b h^{1,9626459} \times h^{0,620845}$

where $d b h$ is diameter at breast height and $h$ total height of the tree.

For downed logs, the length of the fallen dead tree $(l)$ and the maximum diameter $\left(d_{\max }\right)$ and minimum diameter $\left(d_{\min }\right)$ were recorded. The volume $(V)$ was estimated using the formula for the frustum of a circular cone:

$V=(\pi \times l / 3) \times\left[\left(d_{\max } / 2\right)^{2}+d_{\max } \times d_{\min }+\left(d_{\min } / 2\right)^{2}\right]$

To approximate the volumes $(V)$ of living trees per ha we used the following formula:

$V=b a \times h \times \alpha$

where $b a$ is basal area and $h$ is mean height of the two largest trees at the sample point and $\alpha$ represents tree form factor. The latter (estimated to 0.43 ) was derived from the formula provided by Promis (2006) using tree heights between 26 and $36 \mathrm{~m}$.

\section{Statistical analysis}

We used multiple linear regression to analyze the relationships between past land use and variables on forest structure and composition. Age, height and diameter of trees, basal area, tree species composition (basal areas of tree species) and living and dead tree volumes derived from nine sample plots were set as dependent variables, and distance to settlement site was set as an independent variable. Since the study site is a small peninsula there is a chance that other factors such as wind and humidity may influence forest structure and composition. Therefore, we included distance to shore as a control variable. Multicollinearity among dependent variables was checked using variance inflation factors and regression coefficient variance proportions (cf. Friendly and Kwan 2009). The datasets of all forest structure variables were logtransformed when necessary to meet assumptions of normality. Differences are reported as significant when $p<0.05$. All statistical analyses were conducted using IBM SPSS statistics 24 for Windows.

\section{Results}

\section{Inventory and sampling of CMTs}

We found in total 26 bark-peelings on 18 older trees at the site, exclusively on $N$. betuloides (Table 1). Of these, 24 were classified as confirmed bark-peelings done by humans; the other two were possible bark-peelings but were of uncertain status due to fire affecting the peel after the bark-peeling had taken place. Twenty-five peels were found on living trees and one was found on a dead tree. In addition, there were several weathered scars on downed logs that could not be analyzed. We also found two trees with bark-peelings that were burnt inside the trunk of the tree but with no evidence of burning in the immediate surrounding forest (Fig. 3b). On average, there were 5.3 bark-peeled trees per ha. The average length of the bark-peelings was $87 \mathrm{~cm}(\mathrm{SD}=39)$, with a variation between 20 and $170 \mathrm{~cm}$. We could detect two different peel shapes: rectangular (Fig. 3c) and tapered (Fig. 3a). Based on the characteristics that we measured, the most frequent bark-peelings inventoried at Río Batchelor were rectangular $(n=$ $21)$ with a mean length of $81 \mathrm{~cm}(\mathrm{SD}=39)$. The tapered peels $(n=5)$ that we registered were generally longer $(109 \mathrm{~cm}, \mathrm{SD}=$ 38), but also generally older. The oldest rectangular bark-peeling was dated to 1833 , as compared to the oldest tapered bark-peeling, which was dated to 1672 (Table 1, Fig. 4). Most trees with a bark-peeling were decayed in the trunk, and especially within a few centimeters inside the exposed wood on the peel. The dendrochronological dating of the peels showed that these trees had been bark-peeled between approximately 1672 and 1940 (Fig. 4).

\section{Present forest structure and composition}

Forest structure varied greatly across the study site (Table 2). $N$. betuloides was the dominant tree species (43-89\% of the 
Table 1 Bark-peelings on Nothofagus betuloides trees (* denotes samples with more difficulties in determining peeling date;-denotes samples impossible to date with satisfactory precision)

\begin{tabular}{lllllll}
\hline ID of tree & Length of peel $(\mathrm{s})(\mathrm{cm})$ & Type & Age of peel & Age of tree & Position x/y (decimal degrees) & Notes on tree \\
\hline 1 & 150,57 & Tapered & $1672^{*}, 1811$ & $>300$ & $53.56030 / 72.31140$ & Living \\
2 & $102,86,70$ & Rectangular & $1892,1899,-$ & $>200$ & $53.56040 / 72.31107$ & Living \\
3 & 104 & Rectangular & 1900 & $>180$ & $53.56058 / 72.31279$ & Dead \\
4 & 120 & Rectangular & 1924 & $>150$ & $53.56039 / 72.31334$ & Living \\
5 & 48 & Rectangular & $1833^{*}$ & $>220$ & $53.56039 / 72.31369$ & Living \\
6 & 90 & Tapered & 1854 & $>250$ & $53.55997 / 72.31364$ & Living, burnt at the base \\
7 & 95 & Rectangular & 1865 & $>200$ & $53.55997 / 72.31530$ & Living \\
8 & $80,20,20$ & Rectangular & $1876,-,-$ & $>250$ & $53.55875 / 72.31839$ & Living \\
9 & 40 & Rectangular & 1833 & $>270$ & $53.55894 / 72.31231$ & Living \\
10 & 170,105 & Rectangular & 1840 & $>280$ & $53.55892 / 72.31183$ & Living \\
11 & 70 & Rectangular & 1913 & $>220$ & $53.55994 / 72.31194$ & Living \\
12 & 74 & Rectangular & 1869 & $>240$ & $53.55994 / 72.31194$ & Living \\
13 & 140 & Tapered & $1786^{*}$ & $>300$ & $53.56043 / 72.31131$ & Living \\
14 & $120,40,26$ & Rectangular &,,--- & - & $53.55956 / 72.31186$ & Living, decayed \\
15 & 100 & Rectangular & 1911 & $>250$ & $53.55901 / 72.31133$ & Living \\
16 & 95 & Rectangular & 1940 & $>100$ & $53.55885 / 72.31155$ & Living \\
17 & 110 & Tapered & 1925 & $>150$ & $53.55886 / 72.31155$ & Living \\
18 & 120 & Rectangular & 1915 & $>130$ & $53.55886 / 72.31156$ & Living \\
\hline
\end{tabular}

total basal area), with $D$. winteri the second and M. magellanica the third most common tree species on the peninsula (11-50\% and 0-29\% of the total basal area, respectively). The forest was multi-aged, the overall mean age being c. 146 (range: 108-184 years) and the oldest dated $N$. betuloides tree recorded in the region being 330 years old. The average height of the trees was $c .30 \mathrm{~m}$ (range: 26$36 \mathrm{~m}$ ), but the $D$. winteri and $M$. magellanica trees had seldom grown higher than $20 \mathrm{~m}$ and $5 \mathrm{~m}$, respectively. The mean tree DBH was $42 \mathrm{~cm}$, but some $N$. betuloides trees reached a diameter of about $170 \mathrm{~cm}$. The largest $D$. winteri and M. magellanica trees we recorded were $c .80 \mathrm{~cm}$ and $40 \mathrm{~cm}$, respectively. Basal area and volume of trees varied considerably among the sample points $\left(30-40 \mathrm{~m}^{2} \mathrm{ha}^{-1}\right.$ and 374-605 $\mathrm{m}^{3} \mathrm{ha}^{-1}$, respectively). Also, the volume of deadwood differed substantially with a mean value of $77 \mathrm{~m}^{3} \mathrm{ha}^{-1}$ (range: $30-174$ $\mathrm{m}^{3} \mathrm{ha}^{-1}$ ).

To analyze the local effects of past land use on present forest structure and composition, we examined the relationships between distance to settlement site and the following variables: tree age, height and diameter, tree species composition, basal area and volume of living and dead trees in nine sample plots. We found significant relationships between distance to settlement site and several variables of which the most important are presented below (Table 3, Fig. 5). Strong $(p<0.01)$ positive correlations were observed between distance to settlement site and present mean tree diameter and volume of deadwood (total and downed trees). Moderate
$(0.01 \leq p<0.05)$ positive correlations were seen between distance to settlement and mean tree age. We also observed changes in tree species composition with increasing distance from the settlement site with increasing basal area of $N$. betuloides and decreasing basal area of $D$. winteri.

\section{Discussion}

This study focused on indigenous Kawésqar historic forest use at an old-growth Nothofagus betuloides forest site in western Patagonia. Our aim was to analyze the occurrence of CMTs and forest structure with dendrochronological methods and interpret past land use in a temporal perspective embracing the last 400 years.

\section{Interpretation of nothofagus bark-peeling at río batchelor}

In the forested peninsula west of Río Batchelor, we found 18 older $N$. betuloides trees with one to three bark-peelings of different sizes which we interpreted as CMTs. CMTs can be identified by their regular shape, by direct tool-marks when marked (or in this case the tree-bark was collected) (CMT Handbook 2001; Östlund et al. 2009). During our field survey we found a substantial number of scars which we could not assert as man-made with certainty, and therefore we may have underestimated the number of CMTs in the surveyed area of 
Fig. 3 Examples of culturally modified trees at the study site: a large tapered bark-peeling; $\mathbf{b}$ tree which has been burnt inside; $\mathbf{c}$ rectangular bark-peeling (lower left); d tool-mark (knife) on barkpeeling (Photos: Lars Östlund)

Fig. 4 Past chronology of barkpeelings inventoried at Río Batchelor. Y-axis indicates the length of the tapered (triangles) and rectangular (squares) peels, and $\mathrm{X}$-axis indicates the estimated date of bark-peeling
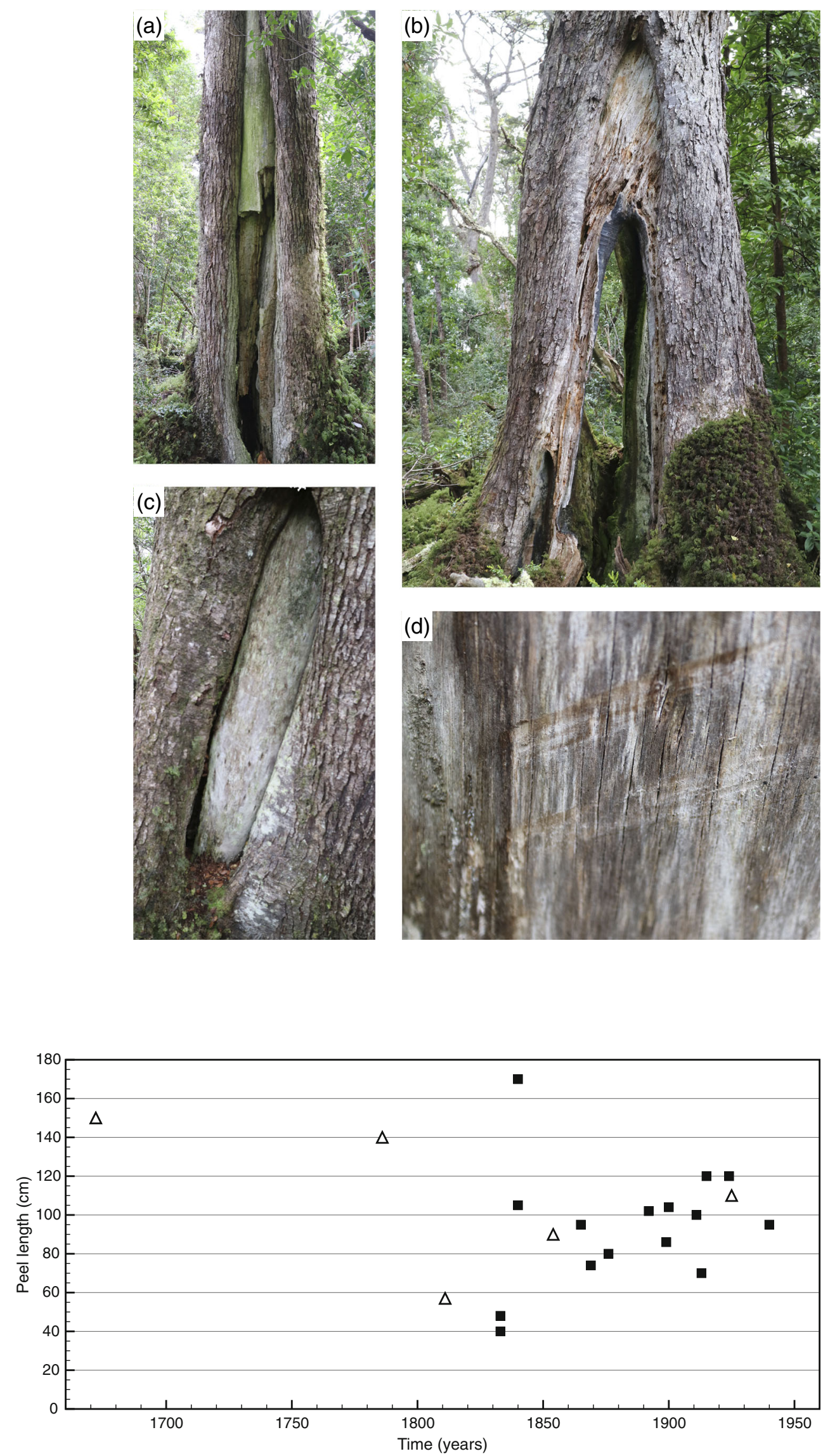
Table 2 Forest structure variables recorded within sample plots; data are means and standard errors (SE), and variation between sample plots (range)

\begin{tabular}{lrcc}
\hline Variables & Mean & SE & Range \\
\hline Tree age (years) & 146.6 & 3.09 & $108-184$ \\
Tree height $(\mathrm{m})^{*}$ & 30.4 & 0.37 & $26-36$ \\
Tree diameter $(\mathrm{cm})$ & & & \\
$\quad$ Mean & 41.6 & 0.85 & $35-60$ \\
Min & 11.9 & 0.32 & $8-16$ \\
Max & 117.4 & 3.73 & $85-170$ \\
Basal area (m $\left.{ }^{2}\right)$ & 37.2 & 0.50 & $30-44$ \\
Tree species composition $(\%)$ & & & \\
$\quad$ N. betuloides & 61.0 & 1.83 & $43-89$ \\
D. winteri & 28.1 & 1.59 & $11-50$ \\
M. magellanica & 10.9 & 1.06 & $0-29$ \\
Volume living trees $\left(\mathrm{m}^{3}\right)$ & 480.9 & 8.50 & $348-563$ \\
Volume dead trees $\left(\mathrm{m}^{3}\right)$ & & & \\
Standing & 11.2 & 1.26 & $0-35$ \\
Downed & 66.5 & 5.63 & $14-167$ \\
Total & 77.7 & 5.65 & $30-174$ \\
\hline
\end{tabular}

* Arithmetical mean tree height in meters of the 100 largest trees $\mathrm{ha}^{-1}$

the peninsula. We did not find any bark-peelings on other dominant, but scarcer, tree species, including $D$. winteri and M. magellanica. This is in accordance with the ethnographic materials and museum collections available in which the use of $N$. betuloides bark is most prominent. According to these sources, Nothofagus bark was very important in the material culture of the Kawésqar and Yagán people: a large variety of artefacts for different uses were made out of the very strong and pliable $N$. betuloides bark (Emperaire 1955; Gusinde 1986, 1991; Legoupil and Lira 2017). Specific techniques and tools made out of animal bones or shells were commonly used to collect the bark and then shape/manufacture these objects. The higher density of bark-peeled trees in the forest nearest to the archaeological site Batchelor I (Fig. 1; San Román et al. 2002; Prieto et al. 2008) and the continuous collection since the seventeenth century until the twentieth century (Fig. 4) indicate that bark from $N$. betuloides trees at Río Batchelor have been taken by Kawésqars for different purposes across a considerable period of time and until relatively recently.

We did not find any very long bark-peelings, as might be expected for building the hull of Nothofagus bark-canoes, an absence that might be considered puzzling as it is known that this type of canoe was built until the early twentieth century (Emperaire 1955). However, in order to construct these craft, $10 \mathrm{~m}$ long strips of bark were cut in a circular fashion around the stem at both ends (Hyades and Deniker 1891; Emperaire 1955), something which killed the tree within a short period of time. And even in the case of collection techniques that would not kill the tree, longer bark-peelings might have fatally exposed the tree to the humid environment and decaying fungi, and these trees may therefore be undetectable today. However, considering the context of multiple use of the landscape by a highly mobile people, we cannot exclude the presence of long bark-peelings at other sites in the region.

The rather short length and the rectangular shape of most bark-peelings and the analysis of bark objects found in the museum collections is an indication that the bark was primarily used for manufacturing small objects such as buckets or beakers. From these objects we could determine that they required a bark strip of $48 \mathrm{~cm}$ on average (range: $33-$ $60 \mathrm{~cm}$ ). These objects can be directly related to the shortest rectangular bark-peelings inventoried at Río Batchelor (Table 1, Fig. 6). It might be expected that one bark-peeling could be used for manufacturing the entire object (including the bottom of the object), or even two objects at the same time. If the length is multiplied by two the bark length required ranges from $c .60-120 \mathrm{~cm}$ and this can be related to longer rectangular peels found at the study site (Table 1). It could also be expected that bigger sections of bark were extracted, with part being lost when manufacturing took place. Another possible use of Nothofagus bark was for the manufacture of ritual masks with rectangular or triangular shapes. Six of them are known from museum collections, with bark pieces ranging from 55.5 to $83 \mathrm{~cm}$, matching well with the length and the tapered shape of some of the bark-peelings inventoried. In addition, the ethnographic literature indicated that smaller
Table 3 Model summary for the relationship between distance to settlement site and several forest characteristics. Only significant relationships are shown $(p<0.05)$

\begin{tabular}{llllrl}
\hline Variables & R2 & R2 (adj) & $\begin{array}{l}\text { B-coefficient } \\
\text { (standardized) }\end{array}$ & T & $P$ \\
\hline Tree age & 0,825 & 0,574 & 0,178 & 3,074 & 0,022 \\
Tree diameter at breast height & 0,796 & 0,728 & 0,061 & 4,802 & 0,003 \\
Basal area $N$. Betuloides & 0,764 & 0,685 & 0,123 & 4,145 & 0,006 \\
Basal area $D$. winteri & 0,547 & 0,396 & $-0,095$ & $-2,671$ & 0,037 \\
Volume of downed deadwood & 0,812 & 0,75 & 0,412 & 5,096 & 0,002 \\
Total volume of deadwood & 0,716 & 0,621 & 0,388 & 3,887 & 0,008 \\
\hline
\end{tabular}



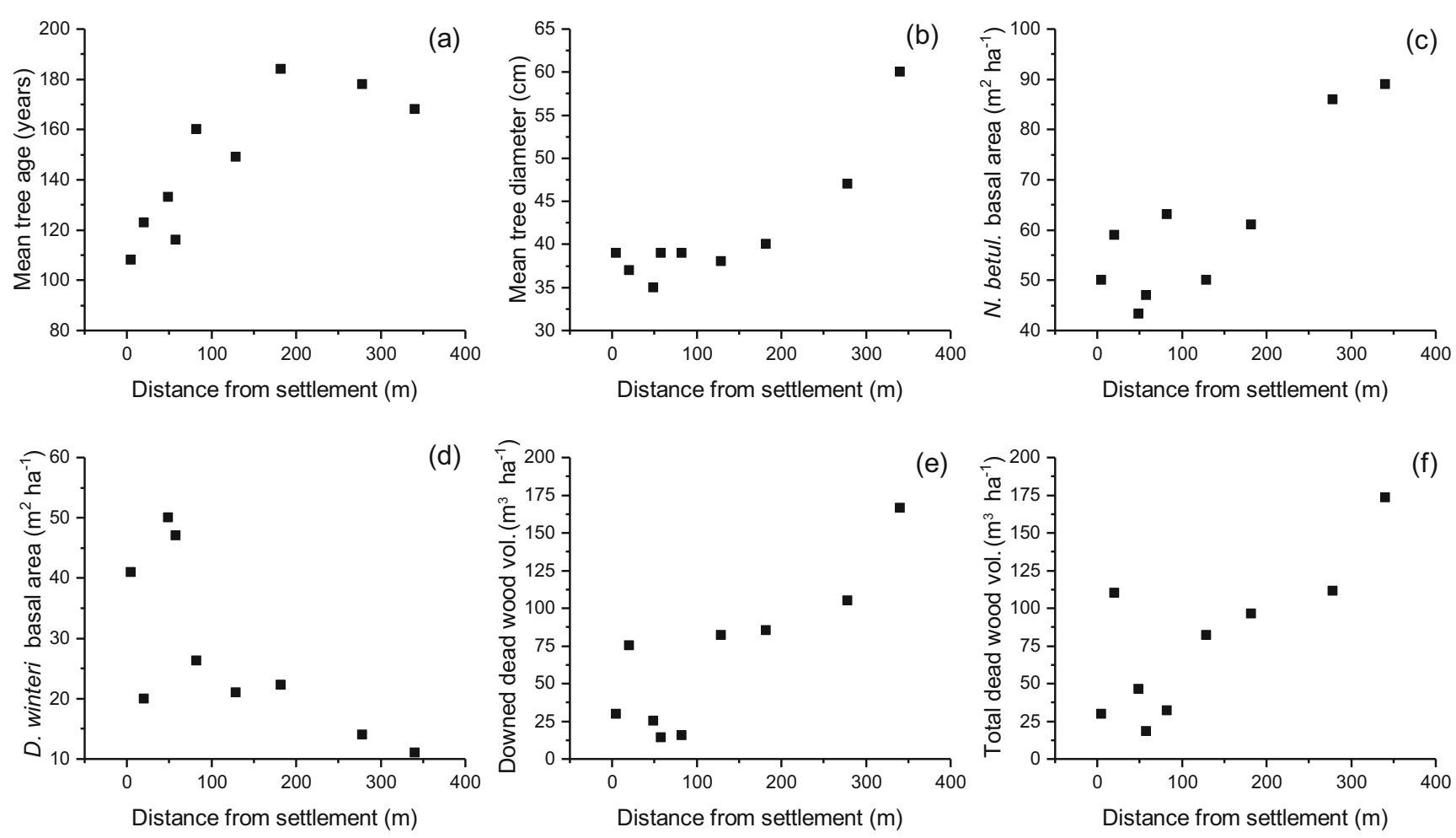

Fig. 5 Relationships between distance from settlement and: a mean tree age; $\mathbf{b}$ mean tree diameter; $\mathbf{c}$ basal area of $N$. betuloides; $\mathbf{d}$ basal area of D. winteri; $\mathbf{e}$ volume of downed logs; and $\mathbf{f}$ total volume of deadwood. All relationships are statistically significant $(p<0.05)$

pieces of bark could be used as wind breaks at the base of huts and for repairing damaged canoes above or below the

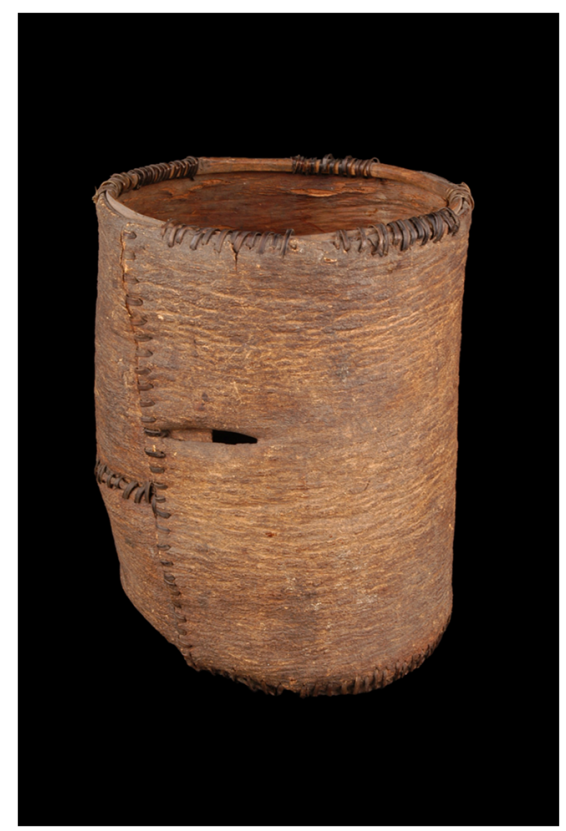

Fig. 6 Bucket $(23 \times 18 \times 18,271 \mathrm{~g})$ made with bark of Nothofagus betuloides collected in the nineteenth century during the WillemsRousson expedition in Patagonia. Source: Collection du Quai Branly, inventory number: 71.1892.35.79 (Photo credit: photo @ musée du quai Branly - Jacques Chirac, Dist. RMN-Grand Palais / image musée du quai Branly - Jacques Chirac) waterline (Hyades and Deniker 1891; Emperaire 1955). Further research must be done in order to link definitively the manufacture of bark objects with CMTs. Nevertheless, the analysis of ethnographic objects from European museums seems to indicate that there may be close relationships.

If bark-peelings can give indications about the nature of land use, CMTs can also inform about timing and the spatial use of the landscape. Due to stem-rot inside the trees and consequent difficulties in preserving and counting tree rings, the dates were somewhat uncertain, but they are within a span of approximately 20 years of the given date in the most difficult cases. Our results show a rather regular collection of bark during the period 1850-1940, which decreases the further one goes back in time, probably due to the mortality of the trees. The most recent bark-peeling we inventoried at Río Batchelor dates from 1940, corresponding with the latest historical record of the Kawésqar in the area (Passini 1951). However, it is notable that rectangular bark-peelings before 1833 could not be found while tapered ones go back to 1672 (Fig. 4). This raises the question of the collection technique and of the motivation for bark-peeling since it is known that at other indigenous sites in the northern hemisphere, bark-peeled trees were not supposed to be killed (Bergman et al. 2004; Östlund et al. 2009). The rather low number of CMTs (5.3 trees per ha) in relation to the lengthy occupation of this Kawésqar settlement may be explained either by the fact that bark-peeled Nothofagus trees do not persist in this harsh environment 
and thus it is difficult to distinguish man-made peels from natural scars, or by the high mobility of Kawésqar, who used the settlement over many decades but in a highly transient manner, leaving little behind in the way of cultural marks on the vegetation. In other studies of CMTs at settlement sites used repeatedly by indigenous groups much higher densities of CMTs are known, up to 22 trees per ha were recorded for example by Rautio et al. (2014).

\section{Forest structure and past Kawésqar land use}

The forest structure at the site gives some clues to previous anthropogenic influence. Many of the ecological variables that we measured were significantly correlated to the distance from the settlement (Table 3, Fig. 5), showing a clear gradient in the forest structure that can be attributed to past indigenous land use. These variables included increasing tree age and tree diameter, increasing basal area of $N$. betuloides at the expense of $D$. winteri, and increasing volumes of deadwood with increasing distance from the ancient Kawésqar settlement. It means that in the most distant areas from the archaeological site, the forest was almost exclusively dominated by old ( $>160$ years old), large diameter $(>40 \mathrm{~cm}) N$. betuloides trees, with large amounts of deadwood - characteristics of an old-growth Nothofagus forest. In the part of the forest nearest the settlement, it was a younger (c. 120 years old), mixed $N$. betuloides$D$. winteri forest type, with much lower volumes of deadwood - very much characteristic of a secondary forest, and very likely a result of important gaps or anthropogenic disturbances.

We could not find any signs of commercial forest management in the peninsula, which means that the forest structure observed today was the result of low intensity land use that stopped about a century ago (as indicated by no $D$. winteri being older than 97 years $(74 \pm 4.6, n=9)$ in the four nearest sampling points to the ancient settlement). $D$. winteri saplings have a better ability to establish in high densities in the understory compared to $N$. betuloides (Rebertus and Veblen 1993), meaning that $D$. winteri, and the forest in general, were probably much scarcer a century ago near the settlement, when it was still used by Kawésqar people. The collection of trees of different sizes for various uses, the use of fire to cut down larger trees (Lira 2015) as we also observed, or smaller $D$. winteri trees for making various items such as harpoons shafts (Maerky 2019) or bows (Emperaire 1955), may have created forest gaps and limited forest regeneration when the settlement was used. Bark-peeling and the associated mortality of trees may also have indirectly influenced the forest structure near the site, where most CMTs where found. The lower deadwood volume can also be explained by human activity at the settlement site aimed at making fire; this has been clearly confirmed in other studies (see for example Josefsson et al. 2010). Deadwood was the main resource for firewood for the Kawésqar (Emperaire 1955). It is worth noting, however, that the lower volume of deadwood could have also been exacerbated by other activities during modern times.

Our overall conclusion concerning the contemporary forest structure at this site is that the area near the archaeological settlement is currently in a state of secondary succession, with a lower amount of deadwood and also with many CMTs, in total showing a high degree of anthropogenic disturbance in the past. We suggest that this forest might once have resembled an "English park" - a more open, park-like forest better suited for a Kawésqar habitation site - a scenario which was described at a similar site in the year 1831 by Captain FitzRoy (FitzRoy 1839).

The archaeological investigations at the site provide evidence of long-term Kawesqár use of the protected inner part of the peninsula. The location of the settlement gave access to marine and land resources as is reflected in the archaeological materials that were found (San Román et al. 2002): projectile tips, biface, scrapers, chopping tools, platelet fragments, nucleus, slabs, flakes, waste and micro-waste (Prieto et al. 2008). Clearly, the site provided protection, fresh water and many valuable resources, and it could thus be expected to be an important place for nomadic indigenous canoers of western Patagonia. However, the temporal pattern of land use cannot be detected by traditional archaeological investigations. This study fills that gap: we show use of the site up until the 1940s and provide evidence of repeated bark harvesting (at least once every 14 years from the late seventeenth century). This confirms that people have been using the site at least since the seventeenth century, along with the forest and marine resources it could provide. The low intense forest use, carried out over many centuries, has shaped the forest structure and left a cultural heritage in the forest ecosystem. Knowledge of this fact has consequences for understanding indigenous resource use in general in this region but also for increasing the respect for the history of the people who lived here during millennia. It is particularly important to use this knowledge, and in close collaboration with today's indigenous communities, when managing protected forests in the region.

\section{Challenges in dating CMTs in southern rainforest ecosystems}

CMT studies in the southern Patagonian Nothofagus forest provide unique research opportunities, but also pose specific challenges. There are many sites on the mainland, as well as on islands in the western archipelago, which feature oldgrowth Nothofagus forest and which have never been commercially logged or exploited in modern times after the abandonment of traditional use by indigenous people in the early twentieth century. These secluded sites constitute preserved and intact environments with a combination of ecological forest structures and archaeological remains. These very 
southerly sites are therefore clear analogues to similar sites in the northern hemisphere in northern Europe (Rautio et al. 2014; Östlund et al. 2009) and in North America (Mobley and Eldridge 1992; Prince 2001). Sites with such characteristics give opportunities to document indigenous peoples' historical land use in detail with dendrochronological techniques, and also to reconstruct the forest structure at the time of indigenous land use.

However, the specific challenges of studying CMTs at these sites - challenges which to some extent separate them from coniferous-dominated sites in the northern hemisphere - are considerable. Firstly, the dominant tree species in the region are deciduous Nothofagus trees, which are far more susceptible to rot by wood fungi when the trees are bark-peeled compared to most coniferous species. Once a peeling is made on a deciduous tree wood fungi penetrates, and the center of the tree, especially the inside of the peel face, rots quickly. Trees with peels are weakened and decay faster, becoming much more prone to windfall; detecting and analyzing bark-peelings on down-logs is difficult, if not impossible in some cases. In contrast, CMTs in coniferous forest can often be detected many centuries after the peel was made due to impregnation of resins in the exposed wood (Östlund et al. 2004). In fact, especially Pine trees with peels may actually be more long-lived compared to trees without peels for the very same reason. CMT analysis is, then, generally more difficult in deciduous forests, and in many cases only estimations of the original peel size and the date of bark-peeling can be made. In light of this, we rather suspect that we have underestimated the real number of CMTs at this site. Yet against this cautious suggestion of underestimation in this case must be set the fact that the Nothofagus trees in these windswept forests tend to suffer natural peeling due to falling stems (snow- and windfallen trees and branches). This makes it very difficult to distinguish between scars of natural origin and CMT peels. And rather frustratingly, the varied size of the Kawésqar objects that have survived in museums does not help that much when seeking to recognize CMTs by their size and shape, in contrast to CMTs in the northern hemisphere, where there is a greater and more reliable knowledge of the shape and size of bark peels (Östlund et al. 2009; Nicolai 2013). The frequency of natural scars, together with our uncertain knowledge about the precise nature of the peel-object relationship, may therefore result in an overestimation of CMTs in Patagonian Nothofagus forest ecosystems, a possibility that future researchers should be aware of. One way to overcome this problem though might be to use novel technique by analyzing peel faces for the presence of micro particles of for example obsidian (cf. Christensen 2017). Such particles, or other foreign material (Fig. 3d), would be a good indicator of an anthropogenic peel.

To conclude on a positive note: CMT research is a wellestablished field in North America, northern Europe and to some extent in other parts of the world (Gottesfeld 1992; Mobley and Eldridge 1992; Carver 2001; Östlund et al.
2009; Turner et al. 2009). Through such research, it has been possible to investigate and understand indigenous peoples' use, affiliation and titles to forestlands (cf. Turner et al. 2009; Östlund et al. 2020). The uniqueness of CMTs is that they 'document' a defined form of land use in situ; furthermore, the act of culturally modifying a tree can be dated to the year. Such studies, then, open new perspectives on and give a temporal precision to our understanding of indigenous land use. While acknowledging the undoubted methodological challenges they pose, our view is that the protected and unlogged forests on the isolated islands in the south-western parts of Patagonia offer spectacular possibilities to expand our knowledge of indigenous archaeology and forest history.

Supplementary Information The online version contains supplementary material available at https://doi.org/10.1007/s10745-020-00200-1.

Acknowledgements We are grateful to Miguel Cáceres Murrie, Andrea Martínez, Museo Nacional de Historia Natural, and Jacqueline Windh for help during the fieldwork; to the crews of the Mary Paz II and the Hans Hanson; to Marlène Baudet for help with the dendrochronological analysis; to Dominique Legoupil for giving access to Passini's journal; and to Sees-editing Ltd for correcting the written English. We are also very thankful for the valuable information about canoe-building and natural resource use provided by the Kawésqar artisan Felicia González González, and the Yagán artisan Martín González Calderón.

Funding This study was funded by Magnus Bergvalls Stiftelse, Sweden; Marie Skodowska-Curie Research and Innovation Staff Exchange (RISE) Program (SuFoRun \#691149); Gifford Hickey, from Spring Creek Conservation; and Laboratoire ESE, Université Paris-Saclay.

\section{Compliance with ethical standard}

Conflict of interest The authors declare that they have no conflict of interest.

Informed consent This research did not involve human nor animals.

Open Access This article is licensed under a Creative Commons Attribution 4.0 International License, which permits use, sharing, adaptation, distribution and reproduction in any medium or format, as long as you give appropriate credit to the original author(s) and the source, provide a link to the Creative Commons licence, and indicate if changes were made. The images or other third party material in this article are included in the article's Creative Commons licence, unless indicated otherwise in a credit line to the material. If material is not included in the article's Creative Commons licence and your intended use is not permitted by statutory regulation or exceeds the permitted use, you will need to obtain permission directly from the copyright holder. To view a copy of this licence, visit http://creativecommons.org/licenses/by/4.0/.

\section{References}

Andersson, R. (2005). Historical land-use information from culturally modified trees. Acta Universitatis Agriculturae Sueciae 2005: 61, Umeå. 
Andersson, R., Östlund, L., and Kempe, G. (2008). How to find the rare trees in the forest - New inventory strategies for culturally modified trees in boreal Sweden. Canadian Journal of Forest Research 38(3): 462-469.

Bayliss-Smith, T., Hviding, E., and Whitmore, T. (2003). Rainforest composition and histories of human disturbance in Solomon Islands. Ambio 32(5): 346-352.

Bergman, I., Östlund, L., and Zackrisson, O. (2004). The use of plants as regular food in ancient subarctic economies: A case study based on Sami use of Scots Pine innerbark. Arctic Anthropology 41(1): 1-13.

Bjerck, H.B. (2009). Colonizing seascapes: comparative perspectives on the development of maritime relations in Scandinavia and Patagonia. Arctic Anthropology 46(1-2): 118-131.

Buergi, M., Östlund, L., and Mladenoff, D. (2017). Legacy effects of human land use: Ecosystems as time-lagged systems. Ecosystems 20: 94-103.

Carver, G. (2001). An examination of indigenous Australian culturally modified trees in South Australia. Doctoral thesis. Department of archaeology, Flinders University, Adelaide.

Chapman, A. (2012). Yaganes del Cabo de Hornos. Encuentros con los europeos antes y después de Darwin. Liberalia Ediciones Ltda. y Pehuén, Santiago de Chile.

Christensen, M. (2017). La industria ósea de los cazadores recolectores: el caso de los nómadas marinos de Patagonia y Tierra del Fuego Punta Arenas, Col. Poblamiento Humano. Universidad de Magallanes, Punta Arenas.

CMT Handbook (2001). Culturally modified trees of British Columbia: A handbook for the identification and recording of culturally modified trees. Archaeology Branch \& Resources Inventory Committee, British Columbia, Canada.

Cruz, G., and Caldentey, J. (2007). Caracterización, silvicultura y uso de los bosques de coihue de Magallanes (Nothofagus betuloides (Mirb.) Blume) en la XII región de Chile. Facultad de Ciencias Forestales, Universidad de Chile, Santiago de Chile.

Dillehay, T.D., Ocampo, C., Saavedra, J., Sawakuchi, A.O., and Vega, R.M. (2015). New archaeological evidence for an early human presence at Monte Verde, Chile. PLOS ONE 10(12): e0145471.

Dillehay, T.D., Ramírez C., Pino, M., Collin, M.B., Rossen, J., and PinoNavarro, D. (2008). Monte Verde: Seaweed, food, medicine, and the peopling of South America. Science 320: 784.

Duplessis, J. (2003). Périple de Beauchesne à la Terre de Feu (16981701): une expédition mandatée par Louis XIV. Texte établi et annoté par Julie Bloch, présenté par Marie Foucard. Transboréal, Paris.

Emperaire, J. (1955). Les nomades de la mer. Gallimard, Paris.

FitzRoy, R. (1839). Voyages of the Adventure and Beagle (Vol. 2). Proceeding of the second expedition 1831-1836 under the command of Captain Robert Fitz-Roy. Henry Colburn, London.

Friendly, M., and Kwan, E. (2009). Where's Waldo? Visualizing collinearity diagnostics. American Statistician 63: 56-65.

Gottesfeld, L. M. J. (1992) The importance of bark products in the aboriginal economies of northwestern British Columbia, Canada. Economic Botany 46(2): 148-157.

Gusinde, M. (1986). Los indios de Tierra del Fuego. Tomo II. Los Yámana. Centro Argentino de Etnología Americana, Consejo Nacional de Investigaciones Científicas, Buenos Aires.

Gusinde, M. (1991). Los indios de Tierra del Fuego. Tomo III, Vol. I. Los Halakwulup. Centro Argentino de Etnología Americana, Consejo Nacional de Investigaciones Científicas, Buenos Aires.

Heckenberger, M.J., Kuikuro, A., Kuikuro, U.T., Russell, J.C., Schmidt, M., Fausto, C., and Franchetto, B. (2003). Amazonia 1492: Pristine forest or cultural parkland? Science 301(5640): 1710-1714.

Heffner, S., and Heffner, T. (2012). Culturally modified trees and traditional management systems: an example from South-Central Yukon. Alaska Journal of Anthropology 10: 95-114.
Hyades, P., and Deniker, J. (1891). Mission Scientifique du Cap Horn 1882-1883. Tome VII Anthropologie, ethnographie. Ministères de la Marine et de l'Instruction Publique, Gauthier-Villars et fils, Paris.

Josefsson, T., Gunnarson, B., Liedgren, L., Bergman, I., and Östlund, L. (2010). Historical human influence on forest composition and structure in boreal Fennoscandia. Canadian Journal of Forest Research 40(5): 872-884

Larson, E.R., Johnson, L.B., Wilding, T.C., Hildebrandt, K.M., Kipfmueller, K.F., and Johnson, L.R. (2019). Faces in the wilderness: a new network of crossdated culturally-modified red pine in the boundary waters canoe area wilderness of Northern Minnesota, USA. Human Ecology 47(5): 747-764.

Legoupil, D., and Lira, N. (2017). Canoeros del fin del mundo. In: Cabo de Hornos. Museo Precolombino, Santiago de Chile, pp. 63-100.

Lira, N. (2015). Embarcations de tradition indigène en Patagonie du Nord/Sud Chili: typologie, technologie et routes de navigation de la Cordillère des Andes à la mer. Doctoral thesis. Université Paris I, Panthéon-Sorbonne, Paris.

Maerky, G. (2019). The concept of «Tendance et Fait » to compensate for the absence of shafts on archaeological fields. Comparison between harpoons of the Yaghan and Kaweskar of South Patagonia and the Aléoutes and Alutiiq of South Alaska. In: Caron-Laviolette E. (ed.). Biais, hiatus et absences en archéologie. Éditions de la Sorbonne, Paris.

Martínez-Crovetto, R. (1968). Nombre de plantas y su utilidad según los indios Onas de Tierra del Fuego. Universidad Nacional del Nordeste, Facultad de Agronomía y Veterinaria, Corrientes, Argentina.

Mobley, C. M., and Eldridge, M. (1992). Culturally modified trees in the Pacific Northwest. Arctic Anthropology 91-110.

Nicolai, D. S. (2013). The archaeological investigation of cedar bark basket trees in western montana: background, methods, and trial study of culturally modified trees. Graduate Student Theses, Dissertations, \& Professional Papers. 962. https://scholarworks. umt.edu/etd/962

Orquera, L.A., Legoupil, D., and Piana, E.L. (2011). Littoral adaptation at the southern end of South America. Quaternary International 239(12): 61-69.

Orquera, L.A., and Piana E.L. (1987). Human littoral adaptation in the Beagle Channel region: The maximum possible age. Quarternary of South America and Arctic Peninsula 5: 133-162.

Orquera, L., and Piana, E. L. (2000). Composición de conchales de la costa del canal Beagle (Tierra del Fuego, República Argentina). Relaciones de la Sociedad Argentina de Antropología XXV. ISSN 0325-2221.

Östlund, L., Ahlberg, L., Zackrisson, O., Bergman, I., and Arno, S. (2009). Bark-peeling, food stress and tree spirits: The use of pine inner bark for food in Scandinavia and North America. Journal of Ethnobiology 29(1): 94-112.

Östlund, L., Bergman, I., Sandström, C., and Brännström, M. (2020). The legal application of ethnoecology: The Girjas Sami Village versus the Swedish State. In: Turner, N.J. (ed.). Plants, people and places. The roles of ethnobotany and ethnoecology in indigenous peoples' land rights in Canada and beyond. McGill-Queen's University Press, Montreal.

Östlund, L., Bergman, I., and Zackrisson, O. (2004). Trees for food: A 3000 year record of subarctic plant use. Antiquity 78: 278-286.

Östlund, L., Zackrisson, O., and Hörnberg, G. (2002). Trees on the border between nature and culture: Culturally modified trees in boreal Scandinavia. Environmental History 7(1): 48-68.

Passini, B. (1951). Ms. Journal de voyage. Archives Emperaire et Laming, dépôt D. Legoupil, Maison de l'Archéologie et de l'Ethnologie, Nanterre.

Piana, E.L., and Orquera, L. (2009). The southern top of the world: The first peopling of Patagonia and Tierra del Fuego and the cultural 
endurance of the Fueguian sea-nomads. Arctic Anthropology (46): $103-107$.

Pisano, E.V. (1981). Bosquejo fitogeografico de Fuego-Patagonia. Anales del Instituto de la Patagonia 12: 159-171.

Prieto, A., and Labarca, R. (2011). Los sitios arqueológicos del Pleistoceno Final de Fuego-Patagonia austral: nuevos hallazgos, nuevos problemas. Boletin de Arqueologia PUCP 15: 357-383.

Prieto, A., San Román, M., Reyes, O., and Bahamonde, G. (2008). Línea de base de los recursos culturales y antecedentes históricos del AMCP-MU Francisco Coloane. Centro de Estudios del Hombre Austral, Instituto de la Patagonia, Universidad de Magallanes, Punta Arenas.

Prince, O. (2001). Dating and interpreting pine cambium collection scars from two parts of the Nechako river drainage. British Columbia Journal of Archaeological Science 28: 253-263.

Promis, A. (2006). Funciones de volumen local y general para coihue de Magallanes. Informe del proyecto FONDEF "Incorporación de los bosques de coihue de Magallanes al manejo forestall para la diversificación e incremento de la producción en la XII Región". Universidad de Chile, Departamento de Silvicultura, Santiago de Chile.

Rautio, A.M., Josefsson, T., and Östlund, L. (2014). Sami resource utilization and site selection: Historical harvesting of inner bark in northern Sweden. Human Ecology 42(1): 137-146.

Rebertus, A.J., and Veblen, T.T. (1993), Structure and tree-fall gap dynamics of old-growth Nothofagus forests in Tierra del Fuego, Argentina. Journal of Vegetation Science 4: 641-654.
San Román, M., Morello, F., and Prieto. A. (2002). Nuevos antecedentes sobre explotación de recursos faunísticos en el mar de Otway y canales adyacente. Anales del Instituto de la Patagonia 30: 147-154.

Sarmiento de Gamboa, P. (1950). Viajes al estrecho de Magallanes (1579-1584) Recopilación de sus relaciones sobre los dos viajes al estrecho y de sus cartas y memorias. Con un Apéndice Documental sobre su Vida y sus Viajes. Emecé, Buenos Aires.

Steward, H. (1984). Cedar: Tree of life to the Northwest coast indians. University of Washington Press, Seattle.

Thompson, J., Brokaw, N., Zimmerman, J.K., Waide, R.B., Everham, E.M., Lodge, D.J., Taylor, C.M., Garcia-Montiel, D., and Fluet, M. (2002). Land use history, environment, and tree composition in a tropical forest. Ecological Applications 12(5): 1344-1363.

Turner, N.J., Ari, Y., Berkes, F., Davidson-Hunt, I., Ertug, Z.F., and Miller, A. (2009). Cultural management of living trees: An international perspective. Journal of Ethnobiology 29(2): 237-270.

Veblen, T. T. (2007). Temperate forests of the Southern Andean Region. In: Veblen, T.T., Orme, A., and Young, K. (eds.). Physical geography of South America. Oxford University Press, New York.

Vila-Mitjà A., and Estévez Escalera. J. (2017). Fichas de los materiales etnográficos fueguinos en museos europeos. https:/hdl.handle.net/ 10261/159205 (accessed in Nov 2019).

Zárraga, C. (2016). Cristina Calderón: Memorias de mi abuela Yagán. La Prensa Austral, Punta Arenas.

Publisher's note Springer Nature remains neutral with regard to jurisdictional claims in published maps and institutional affiliations. 